\title{
Tingkat Pendidikan dan Pengetahuan Ibu Hamil dengan Status Anemia
}

\author{
Filius Chandra $^{1}$, Dini Junita ${ }^{2}$, Tina Yuli Fatmawati ${ }^{3}$ \\ ${ }^{1,2,3}$ Program Studi Ilmu Gizi, Sekolah Tinggi Ilmu Kesehatan Baiturrahim Jambi, Indonesia \\ Program Studi DIII Keperawatan, \\ Sekolah Tinggi Ilmu Kesehatan Baiturrahim Jambi, Indonesia \\ Email: filiuschandra1314@gmail.com ${ }^{1}$, dinijunita.dj.dj@gmail.com², \\ tinayulifatmawati@gmail.com ${ }^{3}$
}

\begin{abstract}
Abstrak
Pendahuluan: Kehamilan adalah salah satu masa yang terpenting untuk pertumbuhan janin. Kebutuhan akan zat gizi juga meningkat sejalan dengan pertambahan umur kehamilan. Asupan gizi yang tidak mencukupi pada ibu hamil dapat menyebabkan anemia. Ibu hamil dengan kekurangan asupan gizi dapat meningkatkan terjadinya resiko keguguran bahkan kematian perinatal. Pengetahuan gizi yang cukup dapat membantu seseorang belajar bagaimana menyimpan, mengolah serta menggunakan bahan makanan yang berkualitas untuk dikonsumsi

Tujuan: Tujuan dari penelitian ini adalah untuk mengetahui hubungan pendidikan dan pengetahuan dengan status anemia ibu hamil di Puskesmas Simpang Kawat Kota Jambi.

Metode: Penelitian ini merupakan penelitian deskriptif korelatif dengan pendekatan cross sectional. Sampel dengan menggunakan teknik total samplingberjumlah 41 responden, Analisa data yang digunakan adalah analisa Univariat dan $\mathrm{Bi}$ variat dengan uji statistic Chi Square.

Hasil: Hasil uji statistis diketahui ada hubungan yang bermakna antara pendidikan dan Pengetahuan responden dengan status anemia ibu hamil dengan nilai $0.000(\mathrm{p}<0.005)$.

Kesimpulan: Pentingnya dilaksanakan edukasi kesehatan tentang anemia selama kehamilan sehingga tidak terjadi komplikasi pasca kehamilan.
\end{abstract}

Kata Kunci: pendidikan, pengetahuan, status anemia, ibu hamil

\section{Pendahuluan}

Upaya kesehatan Ibu dan Anak adalah upaya dibidang kesehatan yang menyangkut pelayanan dan pemeliharaan ibu hamil, ibu bersalin, ibu menyusui, bayi,dan balita serta anak

\begin{abstract}
Introduction: Pregnancy is the most important for fetal growth. The need for iron also increases with increasing gestational age. Inadequate nutritional intake in pregnant women can cause anemia. Mothers with malnutrition can increase the risk of miscarriage and perinatal death. High education is expected to increase knowledge. Nutritional knowledge can help someone learn how to store, process and use quality food ingredients for consumption.

Objective: The purpose of this study was to determine the relationship of education and knowledge on the status of anemia in pregnant women at the PuskesmasSimpang Kawat Kota Jambi.

Method: This research is a correlative descriptive study with a cross-sectional approach. Sampling techniquesused in the sample is a total of 41 respondents, the data analysis used was Univariate and Bivariate analysis with Chi Square.

Results: The results found a significant relationship between education and knowledge of respondents with anemia status of pregnant women with 0,000 ( $p<0.005)$.

Conclusion: The importance of health education carried out about anemia during pregnancy so that complications do not occur after pregnancy.of the study conducted.
\end{abstract}

Keywords: education, knowledge, anemia status, pregnant women

prasekolah. Seorang ibu berperan penting dalam pertumbuhan bayi dan perkembangan anak. Gangguan kesehatan yang dialami seorang ibu yang sedang hamil dapat mempengaruhi 
kesehatan janin dalam kandungannya hingga kelahiran dan masa pertumbuhan anaknya.

Dimasa kehamilan ibu harus mempersiapkan diri sebaik-baiknya untuk menyambut kelahiran bayinya. Ibu yang sehat akan melahirkan bayi yang sehat pula. Salah satu faktor yang mempengaruhi terhadap kesehatan ibu adalah keadaan gizi ibu. Kebutuhan gizi ibu dan janin untuk pertumbuhan dan perkembangan pada masa kehamilan harus memenuhi kebutuhan gizi karena gizi janin bergantung pada gizi ibu.

Gangguan dalam kehamilan dapat terjadi apabila masukkan gizi pada ibu hamil tidak sesuai dengan kebutuhan, baik gangguan terhadap ibu maupun janin yang dikandungnya. Status gizi ibu sebelum dan selama hamil dapat mempengaruhi pertumbuhan janin yang sedang dikandung. Ibu hamil akan melahirkan bayi yang sehat, cukup bulan dengan berat badan normal apabila status gizi ibu normal pada masa sebelum dan selama kehamilan. Dengan kata lain bayi yang akan dilahirkan sangat tergantung pada keadaan gizi ibu sebelum dan selama hamil.

Anemia pada ibu hamil sangat terkait dengan mortalitas dan morbiditas pada ibu dan bayi, termasuk risiko keguguran, lahir mati, prematuritas dan berat bayi lahir rendah.World Health Organization (WHO) mendefinisikan anemia sebagai tingkat hemoglobin $(\mathrm{Hb})<11$ $\mathrm{g} / \mathrm{dl}$ pada kehamilan dan $10 \mathrm{~g} / \mathrm{dl}$ postpartum. Saat ini, tidak ada rekomendasi WHO mengenai penggunaan titik potong hemoglobin yang berbeda untuk anemia pada trimester II, namun diketahui bahwa selama trimester II kehamilan, konsentrasi hemoglobin berkurang sekitar 0,5 g/dl Anemia pada ibu hamil sangat terkait dengan mortalitas dan morbiditas pada ibu dan bayi, termasuk risiko keguguran, lahir mati, prematuritas dan berat bayi lahir rendah.

Anemia pada umumnya terjadi di seluruh dunia, terutama di negara berkembang (developing countries) dan pada kelompok sosioekonomi rendah. Pada kelompok dewasa, anemia terjadi pada wanita usia reproduksi, terutama wanita hamil dan wanita menyusui karena mereka yang banyak mengalami defisiensi Fe. Secara keseluruhan, anemia terjadi pada $45 \%$ wanita di negara berkembang dan $13 \%$ di negara maju (developed countries). Di Amerika, terdapat $12 \%$ wanita usia subur (WUS) 15-49 Tahun, dan 11\% wanita hamil usia subur mengalami anemia.

Minggu-minggu pertama kehamilan adalah masa ketika organ tubuh yang penting terbentuk. Kekurangan gizi pada minggu-minggu ini dapat menimbulkan kelainan pada bayi atau bahkan kelahiran premature.Ketika seorang wanita dinyatakan hamil, perubuhan fisiologis tubuh turut berubah, sehingga kebutuhan gizi juga akan berubah ${ }^{3}$ Pertumbuhan dan perkembangan janin sangat dipengaruhi oleh asupan gizi ibu karena kebutuhan gizi janin berasal dari ibu. Status gizi ibu sebelum hamil dan selama hamil mempengaruhi status gizi ibu dan bayi. Pertumbuhan dan perkembangan janin sangat dipengaruhi oleh asupan gizi ibu karena kebutuhan gizi janin berasal dari ibu.

Kondisi bayi dalam kandungan seorang ibu sangat dipengaruhi keadaan gizi ibu sebelum dan selama mengandung. Wanita hamil berisiko mengalami kekurangan energi kronik (KEK) jika memiliki lingkar lengan atas (LILA) kurang dari $23,5 \mathrm{~cm}$. ibu hamil dengan KEK berisiko melahirkan bayi berat lahir rendah (BBLR). BBLR akan membawa risiko kematian, gangguan pertumbuhan dan perkembangan anak. KEK juga bisa menjadi penyebab tidak langsung kematian ibu, karena KEK pada wanita hamil bisa menjadi salah satu penyebab terjadinya anemia dalam kehamilan. Anemia pada kehamilan bisa menyebabkan perdarahan yang nantinya bisa mengakibatkan kematian baik pada ibu maupun pada janin/ bayi yang dilahirkan.

Data yang diperoleh menyebutkan jumlah perempuan yang meninggal karena komplikasi selama kehamilan dan persalinan mengalami penurunan sebesar $45 \%$ dari perkiraan 523000 pada Tahun 1990dan 289 000 pada Tahun 2013. Peningkatan kesehatan sangatlah penting, tetapi setiap tahuntingkatpenurunannya masihkurang dari yang harapkan untuk mencapai tujuan pembangunan Milenium Development Goal's (MDG's).Target penurunanangka kematian ibu sebesar $75 \%$ antara Tahun 1990 dan 2015. Asupan gizi yang 
tidak mencukupi pada ibu hamil ini juga dapat menyebabkan Kurang Energi Kronis (KEK). Risiko terjadinya KEK dapat dialami oleh Wanita Usia Subur (WUS). World Health Organization (WHO) memperkirakan prevalensi Berat Bayi Lahir Rendah (BBLR) sebesar 15\% sampai $20 \%$ diseluruh dunia dan $96 \%$ kejadian BBLR terjadi di Negara berkembang termasuk Indonesia.

Berdasarkan Survei Demografi dan Kesehatan Indonesia, angka kematian ibu (AKI) melonjak drastis 359 per 100.000 kelahiran hidup. Beberapa penyebab langsung kematian ibu di Indonesia masih didominasi oleh perdarahan $(42 \%)$, eklampsia (13\%), dan infeksi (10\%). Anemia dan kekurangan energi kronik pada ibu hamil menjadi penyebab utama terjadinya perdarahan dan infeksi. Tujuh dari sepuluh wanita hamil di Indonesia mengalami anemia. Berdasarkan data Dinkes Kota Jambi Tahun 2018 didapatkan jumlah ibu hamil dengan anemia di 20 Puskesmas di Kota Jambi Tahun 2016 S/D 2017meningkat setiap tahun. Salah satunya di Puskesmas Simpang Kawat terdapat jumlah kasus ibu hamil dengan amenia pada tahun 2016 sebanyak 12 orang dan pada tahun 2017 meningkat sebanyak (30,3\%) 191 orang.

Beberapa penelitian yang dilakukan di negara berkembang bahwa separuh dari penyebab terjadinya Berat Bayi Lahir Rendah (BBLR) adalah status gizi ibu, termasuk tinggi badan ibu, berat badan ibu sebelum kehamilan dan penambahan berat badan selama kehamilannya.

Berdasarkan studi pendahuluan yang dilakukan pada bulan Januari 2019, pada 10 respondendidapatkan data bahwa sebanyak 4 orang berpendidikan SMP dan 6 orang berpendidikan SMA dan PT, dari 7 responden memiliki pengetahuan yang kurang mengenai anemia dalam kehamilan, sebagian besar tidak memahami penyebab terjadinya anemia dan dampak dari anemia pada kehamilan. 4 orang diantaranya menderita anemia .

Ibu hamil dengan pengetahuan gizi baik diharapkan dapat memilih asupan makanan yang bernilai gizi baik dan seimbang bagi dirinya sendiri beserta janin dan keluarga, dengan pengetahuan gizi yang cukup dapat membantu seseorang belajar bagaimana menyimpan, mengolah serta menggunakan bahan makanan yang berkualitas untuk dikonsumsi menurut kebutuhannya.

Pengetahuan mengenai anemia pada saat kehamilan sangatlah penting bagi ibu-ibu yang sedang hamil, karena pengetahuan dapat mempengaruhi sikap dan perilaku mereka dalam menjaga pola konsumsi makanan seharihari sehingga dapat mencegah terjadinya anemia pada saat kehamilan. Sedangkan status gizi pada saat kehamilan juga perlu diperhatikan, kebutuhan akan zat besi juga meningkat sejalan dengan pertambahan umur kehamilan.Tujuan pda penelitian ini untuk mengetahui hubungan pendidikan dan pengetahuan terhadap status anemia ibu hamil di Puskesmas Simpang Kawat Kota Jambi.

\section{Metode}

Penelitian ini merupakan penelitian deskriptif korelatif dengan pendekatan cross sectional. Populasi dalam penelitian ini adalah seluruh ibu Hamil trimester I dan II di Puskesmas Simpang awat Kota Jambi.Sampel diambil dengan menggunakan teknik total samplingberjumlah 41 responden yang diperoleh dari bulan April s/d Juni 2019. Sumber data yang digunakan data primer yang diperoleh dari responden dan data sekunder diperoleh dari Puskesmas yang berisi identitas responden, nilai HB dalam bentuk lembar observasi, Buku KIA dan Catatan Rekam Medis. Adapun instrument yang dipergunakan untuk mengumpulkan data lembar kuesioner. Analisis data dalam penelitian ini dilakukan dengan menggunakan analisis univariat yaitu dengan menyederhanakan /memudahkan untuk menginterpretasi data kedalam bentuk penyajian secara tekstuler, tabuler dari distribusi variabel penelitian yang diteliti dan dianalisis bivariat untuk mengetahui hubungan pendidikan dan pengetahuan terhadapstatus anemia ibu hamil di Puskesmas Simpang Kawat Kota Jambi analisa dengan uji statistic Chi Square.

\section{Hasil \\ Analisis univariat}


Gambaran Usia Responden

Jumlah ibu hamil berdasarkan usia di Puskesmas Simpang Kawat Kota Jambi Tahun 2019 dapat dilihat pada tabel 1 berikut ini:

Tabel 1. Distribusi Ibu Hamil Berdasarkan Kategori usia(n=41)

\begin{tabular}{cccc}
\hline No & Usia & n & \% \\
\hline 1 & $17-25$ tahun & 18 & 43,9 \\
2 & $26-35$ tahun & 19 & 46,3 \\
3 & $36-45$ tahun & 4 & 9,8 \\
\multicolumn{2}{c}{ Total } & 41 & 100 \\
\hline
\end{tabular}

Berdasarkan Tabel 1 Umur terbanyak berada diusia 26 - $35(46,3 \%)$

Gambaran Tingkat Pendidikan Responden

Jumlah ibu hamil berdasarkan tingkat pendidikan di Puskesmas Simpang Kawat Kota Jambi Tahun 2019 dapat dilihat pada tabel 2 berikut ini:

Tabel 2. Distribusi Ibu Hamil Berdasarkan tingkat pendidikan $(n=41)$

\begin{tabular}{cccc}
\hline No & $\begin{array}{c}\text { Tingkat } \\
\text { Pendidikan }\end{array}$ & n & \% \\
\hline 1 & SD & 0 & $0 \%$ \\
2 & SMP & 10 & 24,4 \\
3 & SMA & 28 & 68,3 \\
4 & Perguruan & 3 & 7,3 \\
& Tinggi & & \\
& Jumlah & 41 & 100 \\
\hline
\end{tabular}

Berdasarkan Tabel 2 diatas mayoritas tingkat pendidikan responden tinggi SMA sebanyak 28 orang $(68,3 \%)$.

Gambaran Pengetahuan ibu Terhadap Status Anemia Ibu Hamil di Puskesmas Simpang Kawat Kota Jambi Tahun 2019dapat dilihat pada tabel dibawah ini:

Tabel 3. DistribusiPengetahuan ibu Terhadap Status Anemia Ibu Hamil $(\mathrm{n}=41)$

\begin{tabular}{llcc}
\hline No & Pengetahuan & n & \% \\
\hline 1 & Baik & 29 & 70,7 \\
2 & Kurang baik & 12 & 29,3 \\
& Total & 41 & 100 \\
\hline
\end{tabular}

Berdasarkan Tabel 3 mayoritas pengetahuan responden baik 29 (70,7\%).
Gambaran status anemia Ibu Hamil di Puskesmas Simpang Kawat Kota Jambi Tahun 2019 dapat dilihat pada tabel dibawah ini:

Tabel 4. Distribusi Status Anemia Ibu Hamil $(\mathrm{n}=41)$

\begin{tabular}{llcc}
\hline No & Status anemia & n & $\%$ \\
\hline 1 & Tidak anemia & 27 & $62,8 \%$ \\
2 & Anemia & 14 & $32,6 \%$ \\
Total & & 41 & $100 \%$ \\
\hline
\end{tabular}

Berdasarkan Tabel 4 mayoritas status anemia ibu hamil terbanyak tidak anemia 27 responden $(68,2 \%)$

\section{Analisis Bivariat}

Berikut analisis Hubungan Pendidikan Terhadap Status Anemia Ibu Hamil di Puskesmas Simpang Kawat Kota Jambi, dapat dilihat pada tabel berikut ini :

Tabel 5. Hubungan pendidikan Terhadap Status Anemia Ibu Hamil di Puskesmas Simpang Kawat Kota Jambi Tahun 2019.

\begin{tabular}{|c|c|c|c|c|c|c|}
\hline \multirow{3}{*}{$\begin{array}{l}\text { Pen- } \\
\text { didi- } \\
\text { kan }\end{array}$} & \multicolumn{4}{|c|}{ Status anemia } & \multicolumn{2}{|c|}{ Jumlah } \\
\hline & \multicolumn{2}{|c|}{$\begin{array}{c}\text { Tidak ane- } \\
\text { mia }\end{array}$} & \multicolumn{2}{|c|}{ anemia } & \multirow[b]{2}{*}{$\mathbf{n}$} & \multirow[b]{2}{*}{$\%$} \\
\hline & $\mathbf{n}$ & $\%$ & $\mathbf{n}$ & $\%$ & & \\
\hline Tinggi & 25 & 80,6 & 6 & 29,4 & 31 & 100 \\
\hline Rendah & 2 & 20,0 & 8 & 80,0 & 10 & 100 \\
\hline Jumlah & 27 & 65,9 & 14 & 34,1 & 41 & 100 \\
\hline $\mathrm{p}$-value & 0.00 & & & & & \\
\hline
\end{tabular}

Hasil diatas menunjukkan bahwa dari 10 responden yang memiliki pendidikan rendah 2 $(20,0 \%)$ responden memiliki status tidak anemia dan $8(80,0 \%)$ responden memiliki status anemia. Adapun dari 31 responden yang memiliki pendidikan tinggi $25(80,6 \%)$ responden memiliki status tidak anemia dan $6(29,4 \%)$ responden memiliki status anemia. Analisis Chi Square menunjukkan nilai p-value $=0,00<0,05$ artinya ada hubungan Pendidikan dengan Status Anemia Ibu Hamil.

Berikut analisis Hubungan Pengetahuan Terhadap Status Anemia Ibu Hamil di Puskesmas Simpang Kawat Kota Jambi, dapat dilihat pada tabel berikut ini : 
Tabel 6. Hubungan Pengetahuan Terhadap Status Anemia Ibu Hamil di Puskesmas Simpang Kawat Kota Jambi Tahun 2019.

\begin{tabular}{|c|c|c|c|c|c|c|}
\hline \multirow{3}{*}{$\begin{array}{l}\text { Pengeta } \\
\text { huan }\end{array}$} & \multicolumn{4}{|c|}{ Status anemia } & \multicolumn{2}{|c|}{ Jumlah } \\
\hline & \multicolumn{2}{|c|}{$\begin{array}{l}\text { Tidak ane- } \\
\text { mia }\end{array}$} & \multicolumn{2}{|c|}{ anemia } & \multirow[b]{2}{*}{$\mathbf{n}$} & \multirow[b]{2}{*}{$\%$} \\
\hline & $\mathbf{n}$ & $\%$ & $\mathbf{n}$ & $\%$ & & \\
\hline Baik & 25 & $\begin{array}{l}86, \\
2\end{array}$ & 4 & 13,8 & $\begin{array}{l}2 \\
9\end{array}$ & 100 \\
\hline $\begin{array}{l}\text { Kurang } \\
\text { baik }\end{array}$ & 2 & 16,7 & 10 & 83,3 & $\begin{array}{l}1 \\
2\end{array}$ & \\
\hline Jumlah & 27 & $\begin{array}{l}65 \\
9\end{array}$ & 14 & 34,1 & $\begin{array}{l}4 \\
1\end{array}$ & \\
\hline $\mathrm{p}$-value & 0,00 & & & & & \\
\hline
\end{tabular}

Hasil diatas menunjukkan bahwa dari 12 responden yang memiliki pengetahuan kurang baik $2(16,7 \%)$ responden memiliki status tidak anemia dan $10(83,3 \%)$ responden memiliki status anemia. Dari 29 responden yang memiliki pengetahuan baik $25(86,2 \%)$ responden memiliki status tidak anemia dan $4(13,8 \%)$ responden memiliki status anemia

Analisis Chi Square menunjukkan nilai p-value $=0,000<0,05$ artinya adahubungan Pengetahuan Terhadap StatusAnemia Ibu Hamil di Puskesmas Simpang Kawat Kota Jambi.

\section{Pembahasan}

Hasil penelitian diperoleh ada hubungan Pendidikan dan Pengetahuan Terhadap Status Anemia Ibu Hamil di Puskesmas Simpang Kawat Kota Jambi. Pada penelitian ini sebagian besar ibu hamil yang memiliki pendidikan rendah mengalami status anemia selama kehamilan. Demikian juga halnya dengan pengetahuan, pada responden yang berpengetahuan kurang baik sebagian besar memiliki status anemia masa kehamilan.

Tingkat pendidikan juga mempunyai hubungan dengan tingkat kesehatan. Semakin tinggi tingkat pendidikan semakin mudah menerima konsep hidup sehat secara mandiri, kreatif dan berkesinambungan. Tingkat Pendidikan juga sangat mempengaruhi kemampuan dalam menerima informasi gizi, menentukan atau mempengaruhi mudah tidaknya seseorang menerima suatu pengetahuan, semakin tinggi pendidikan maka seseorang akan lebih mudah menerima informasi gizi.

Menurut Walyani, tingkat pendidikan ibu sangat mempengaruhi bagaimana seseorang untuk bertindak dan mencari penyebab serta solusi dalam hidupnya. Orang yang berpendidikan tinggi biasanya akan bertindak lebih rasional. Oleh karena itu orang yang berpendidikan akan lebih mudah menerima gagasan baru. Demikian halnya dengan ibu yang berpendidikan tinggi akan memeriksakan kehamilannya secara teratur demi menjaga keadaan kesehatan dirinya dan anak dalam kandungannya. ${ }^{1}$

Pengetahuan merupakan domain yang sangat penting untuk terbentuknya tindakan seseorang. Pengetahuan diperlukan sebagai dukungan dalam menumbuhkan rasa percaya diri maupun sikap dan perilaku setiap hari, sehingga dapat dikatakan bahwa pengetahuan merupakan fakta yang mendukung tindakan seseorang. Pengetahuan merupakan salah satu faktor yang mempengaruhi perilaku kesehatan. Ibu hamil yang mengetahui dan memahami akibat anemia serta cara mencegah anemia akan mempunyai perilaku dan tindakan yang positif sehingga dapat terhindar dari dampak dan risiko anemia pada masa kehamilan. menyatakan bahwa pengetahuan yang baik akan akan mempengaruhi perilaku kesehatan sehingga berpengaruh terhadap perilaku kesehatan.

Hasil penelitian ini sejalan dengan penelitian Purbadewi hasil yang diperoleh bahwa ada hubungan antara tingkat pengetahuan dengan kejadian anemia pada ibu hamil dengan nilai $\mathrm{p}=0,000$. Sama halnya dengan penelitian Anna Mariza, hasil yang diperoleh terdapat hubungan pendidikan dengan anemia ibu hamil dengan P-Value 0,026. Namun penelitian ini tidak sejalan dengan penelitian Diana Sukmaningtyashasil yang diperoleh bahwa tidak ada hubungan antara tingkat pengetahuan dengan kejadian anemia pada ibu hamil di wilayah kerja Puskesmas Gatak. 13,14,15 Pengetahuan yang dimiliki seorang ibu akan mempengaruhi dalam pengambilan keputusan dan juga berpengaruh pada perilakunya. Ibu dengan pengetahuan gizi yang baik kemungkinan akan memberikan gizi yang cukup bagi 
bayinya, ia akan berupaya untuk memenuhi kebutuhan gizinya dan juga calon bayinya.

Pengetahuan yang baik tentang gizi seseorang membuat orang tersebut akan semakin memperhatikan jumlah dan jenis makanan yang dipilihnya untuk dikonsumsi. Ibu hamil yang memiliki pengetahuan gizi kurang akan berperilaku memilih makanan yang menarik panca indra dan tidak memilih menu berdasarkan nilai gizi makanan tersebut. Sebaliknya mereka yang memiliki pengetahuan baik cenderung lebih banyak menggunakan rasional dan pengetahuan tentang nilai gizi makanan tersebut sehingga asupan gizi akan meningkat.

Hal ini sesuai dengan pendapat Notoatmodjo bahwa informasi menjadi salah satu faktor eksternal untuk memperoleh pengetahuan seseorang. Pengetahuan individu sangat mempengaruhi perilaku sehatnya setiap hari. Ibu hamil yang tidak mendapatkan pengetahuan yang cukup tentang kehamilan seringkali mengalami masalah selama kehamilan. Pengetahuan ibu hamil juga mempengaruhi perilakunya dalam menjaga kehamilan. Ibu yang sedang mengalami kehamilan yang pertama biasanya sangat menjaga kehamilannya dengan cara rajin mengkonsumsi asupan-asupan gizi untuk kehamilannya.

Semua wanita hamil memiliki resiko untuk terkena anemia. Remaja putri lebih beresiko menderita anemia daripada remaja putra setiap bulannya mengalami menstruasi, sering kali menjaga penampilan, ingin mendapatkan tubuh ideal sehingga berdiet dan mengurangi makan. ${ }^{16}$ Hal tersebut disebabkan mereka membutuhkan zat besi dan asam folat lebih banyak daripada biasanya. Oleh karena itu disarankan kepada ibu hamil agar sering mencari informasi tentang nutrisi ibu hamil baik dari media cetak maupun elektronik, diharapkan dengan memiliki pendidikan dan pengetahuan yang baik seorang individu akan berusaha menerapkan pengetahuan tersebut ke dalam praktek kehidupannya, seperti pemenuhan gizi seimbang selama kehamilan.

\section{Kesimpulan}

Dari hasil penelitian yang telah dilakukan oleh peneliti maka didapatkan hasil dimana terdapat suatu hubungan yang signifikan antara pendidikan dan tingkat pesengetahun responden yaitu ibu hamil yang mengalami anemia dengan status anemia pada responden tersebut,

\section{Daftar Pustaka}

1. Anna Mariza. Hubungan Pendidikan Dan Sosial Ekonomi Dengan Kejadian Anemia Pada Ibu Hamil Di BPS T Yohan Way Halim Bandar Lampung Tahun 2015, Jurnal Kesehatan Holistik Vol 10, No 1. Diakses Juni 2019.

2. Diana Sukmaningtyas. Hubungan Antara Tingkat Pengetahuan Dan Status Gizi Ibu Hamil Dengan Kejadian Anemia Di Puskesmas Gatak Kabupaten Sukoharjo, Program Studi Kesehatan Masyarakat Fakultas Ilmu Kesehatan Universitas Muhammadiyah Surakarta; 2015. Diakses Juni 2019.

3. Dinkes Propinsi Jambi, Profil Kesehatan Propinsi Jambi; 2016.

4. Fatmah. Gizi Dan Kesehatan Masyarakat. Jakarta: Departemen Gizi FKM UI; 2012.

5. Hariyani, S. Gizi Untuk Kesehatan Ibu Dan Anak. Edisi Pertama, Yogyakarta: Graha Ilmu, Yogyakarta; 2012.

6. Kemenkes Ri, 2017. Riset Kesehatan Dasar, Diakases Juni 2019

7. Kemenkes Ri. Profil Kesehatan Indonesia Tahun 2013. Jakarta: Kemenkes RI; 2014.

8. Notoatmodjo. Promosi Kesehatan Dan Perilaku Kesehatan. Jakarta: Rineka Cipta; 2012

9. Purbadewi, L Dan Ulvie, Y.N.S. 2013.Hubungan Tingkat Pengetahuan Tentang Anemia Dengan Kejadian Anemia Pada Ibu Hamil. Jurnal Gizi Universitas Muhammadiyah Semarang, Volume 2, Nomor 1. Diakses Juni 2019

10. South Australian Perinatal Practice Guidelines. Anaemia In Pregnancy; 2016.

11. Suhartono.S. Wawasan Pendidikan: Sebuah Pengantar Pendidikan. Yogyakarta: Ar-Ruzzmedia; 2008.

12. Sulistyoningsih, H. Gizi Untuk Kesehatan Ibu Dan Anak. Yogyakarta: Graha Ilmu; 2011.

13. Walyani Elisabeth, Siwi. Asuhan Kebidanan. Yogyakarta; 2015

14. Waryana. Gizi Reproduksi. Yogyakarta: Pustaka Rihama; 2010.

15. World Health Organization, 2014, Maternal Mortality, Diakses Juni 2019 
Tingkat Pendidikan dan Pengetahuan Ibu...

16. Muhayati, Anis, and Diah Ratnawati. "Hubungan Antara Status Gizi dan Pola Makan dengan Kejadian Anemia Pada Remaja Putri." Jurnal Ilmiah Ilmu Keperawatan Indonesia 9.01 2019: 563-570. 